\title{
Population dynamics, secondary production and calcification in a Mediterranean population of Ditrupa arietina (Annelida: Polychaeta)
}

\author{
L. Medernach, E. Jordana, A. Grémare*, C. Nozais, F. Charles, J. M. Amouroux \\ Observatoire Océanologique de Banyuls, Université Pierre et Marie Curie, UMR CNRS no. 7621, BP 44, \\ 66651 Banyuls-sur-mer Cedex, France
}

\begin{abstract}
Temporal changes in the distribution of the serpulid polychaete Ditrupa arietina in the Bay of Banyuls-sur-mer were monitored between January 1996 and January 1998. Life-history characteristics, population dynamics, secondary production and calcification were measured at a permanent site between June 1994 and June 1996. Secondary production and calcification were then extrapolated to the whole Bay. $D$. arietina has a 2 yr life cycle with worms first reproducing when they are 1 yr old. Reproduction occurs during spring with several spawning peaks each year. Development is planktotrophic and the duration of the pelagic phase is close to $6 \mathrm{wk}$. Recruitment does not correlate with larval supply due to high mortality rates during the first benthic stage. Mortality follows an exponential model. Growth is best described by a logistic model and is almost restricted to the first year of the life cycle. Density significantly decreased between 1996 and 1998. This pattern resulted from a strong recruitment in the whole bay during 1994, a weaker recruitment restricted to the deeper part of the bay during 1995, and a total absence of recruitment during both 1996 and 1997. Secondary production was between 0.4 and $295.9 \mathrm{~g} \mathrm{DW} \mathrm{m}^{-2} \mathrm{yr}^{-1}$, and 0.1 and $12.3 \mathrm{~g} \mathrm{DW} \mathrm{m}^{-2} \mathrm{yr}^{-1}$, during the June 1994 to June 1995 and the June 1995 to June 1996 time periods, respectively. Calcification was between 17 and $11836 \mathrm{~g} \mathrm{~m}^{-2} \mathrm{yr}^{-1}$, and 2 and $397 \mathrm{~g} \mathrm{~m}^{-2} \mathrm{yr}^{-1}$, during the June 1994 to June 1995 and the June 1995 to June 1996 time periods, respectively. Calcification rates calculated for the June 1994 to June 1995 time period are the highest ever reported for temperate benthic ecosystems.
\end{abstract}

KEY WORDS: Mediterranean - Ditrupa arietina $\cdot$ Polychaete $\cdot$ Population dynamics · Secondary production $\cdot$ Calcification

\section{INTRODUCTION}

The composition of benthic macrofauna associated with soft substrates within the Bay of Banyuls-sur-mer has undergone major changes over the last 25 yr (Grémare et al. 1998b). In sandy bottoms the dominant species during the late 1960 s, the bivalve Spisula subtruncata and the polychaete Nepthys hombergii, have regressed whereas the polychaete Ditrupa arietina (O. F. Müller) has dramatically increased. The latter species was not even cited in the initial description of benthic communities along the French Catalan coast (Guille 1970). It is now the dominant macrofaunal species in the sandy bottoms of the Bay of Banyuls-sur-

\footnotetext{
•Corresponding author. E-mail: gremare@arago.obs-banyuls.fr
}

mer, with adult density reaching more than 3000 ind. $\mathrm{m}^{-2}$ (Grémare et al. 1998b). Such densities are uncommon for the Mediterranean Sea, which is oligotrophic and where macrobenthos is usually only present at low densities (Guille 1970).

Analysis of the spatial distribution of Ditrupa arietina along both the French and the Spanish Catalan coasts has shown that the presence of this species is not restricted to the Bay of Banyuls-sur-mer. High densities have also been found at all of the 8 sites sampled along the portion of coast between Barcelona and Montpellier since 1989 (Grémare et al. 1998a). Thus, the increase of $D$. arietina in this portion of the Gulf of Lions is of regional importance.

Ditrupa arietina is a tubicolous serpulid polychaete with a strong calcareous tusk-shaped tube. The purpose 
of the present investigation was to quantify both its secondary production and calcification. This required the assessment of the main life-history characteristics and population dynamics. Production and calcification were directly measured at a permanent site and then extrapolated to the whole Bay of Banyuls-sur-mer.

\section{MATERIALS AND METHODS}

Life history, population structure and population dynamics. Late oogenesis was assessed by measuring 100 oocytes in 5 females collected weekly at Stn 1 $\left(42^{\circ} 26^{\prime} 082^{\prime \prime} \mathrm{N}, 03^{\circ} 08^{\prime} 421^{\prime \prime} \mathrm{E}, z=18 \mathrm{~m}\right.$, Fig. 1) between March 7 and June 11, 1996. Oocytes from an additional female collected on June 18, 1996, were also examined. For each female, oocyte diameters were measured on the first 100 seen oocytes using an image analysis system based on the software Moch $a^{\circledast}$ coupled with a light microscope. The presence of competent larvae in the water column was assessed between 1993 and 1996 by monitoring the number of juveniles collected weekly in the 2 sediment traps moored at Stn 1 (Grémare et al. 1997). Between May 14 and August 12, 1997, another site (Stn $2 ; 42^{\circ} 29^{\prime} 302^{\prime \prime} \mathrm{N}_{1} 03^{\circ} 08^{\prime} 700^{\prime \prime} \mathrm{E}$, $z=27 \mathrm{~m}$, Fig. 1) was sampled to assess post-metamorphic juvenile mortality. Each week, 3 cores $(5.2 \mathrm{~cm}$ in diameter) were collected by SCUBA divers, fixed in $4 . \%$ formalin and stained with Rose Bengal. Juveniles of Ditrupa arietina were extracted from the sediment by 10 repeated shakings in $5 \mathrm{l}$ of tap water and by sieving on a $40 \mu \mathrm{m}$ mesh. They were then counted under a dissecting microscope.

During January 1996, and then during October 1996, and January 1998, 3 surveys were carried out to assess the spatial distribution of Ditrupa arietina within the Bay of Banyuls-sur-mer. On each of these sampling dates, a total of 78 stations (Fig. 1) were sampled with a $0.1 \mathrm{~m}^{2}$ Van Veen grab. Two grabs were taken at each station. Samples were sieved on a $1 \mathrm{~mm}$ mesh, preserved in $4 \%$ formalin and stained with Rose Bengal. The specimens of $D$. arietina were then carefully sorted and counted. Those with intact tubes were kept for allometric measurements. Tube major axis length (MAL) was measured using the image analysis system described above. This parameter wàs chosen because it correlated better with individual dry weight than tube perimeter and surface.. Individual dry weights (DW in $\mathrm{mg}$ ) were computed by using the following allometric relationship: $\mathrm{DW}=\mathrm{e}^{-8: 695} \mathrm{MAL}^{2.872}\left(\mathrm{r}^{2}=0.958\right.$, based on 345 living worms), with MAL expressed in $\mathrm{mm}$. Tube dry weights (TDW in $\mathrm{mg}$ ) were also computed from MAL $(\mathrm{mm})$ by using an equation of the same form: TDW $=e^{-4.874} \mathrm{MAL}^{2.839}\left(\mathrm{r}^{2}=0.962\right.$, based on 246 living worms).
Population structure and dynamics were monitored at Stn 1 between June 1994 and June 1996. This station was sampled every other week by SCUBA divers. Three $0.1 \mathrm{~m}^{2}$ benthic samples were taken by scraping the first $5 \mathrm{~cm}$ of sediment and then treated as described above. Population structure was assessed through sizefrequency histograms based on MAL (size interval of $1 \mathrm{~mm}$ ). Because of the simplicity of the population structure, it was not necessary to use a sophisticated computing procedure to separate cohorts. Mortality was assessed by monitoring temporal changes in the density of the 1994 cohort, and by fitting an exponential model. Growth was assessed by monitoring temporal changes in the average individual dry weight of worms belonging to the 1994 cohort and by fitting a logistic model. Densities were monitored at Stn 2 between December 1996 and January 1998 using the same sampling strategy.

Production and calcification. Production and calcification at Stn 1 were calculated using the increment summation technique (Crisp 1971). This procedure was carried out both on DW (which can be converted into ash-free dry weight by using a conversion factor of 0.892), and on TDW. Ninety-five \% confidence intervals were computed by generating 500 production (or calcification) estimates based on a randomly chosen (i.e., among the 3 replicates) density per sampling date (Morin et al. 1987).

We used the results of the January 1996 distribution survey together with the production values measured at $\operatorname{Stn} 1$ to infer the production of Ditrupa arietina in the whole Bay of Banyuls-sur-mer during both the June 1995 to June 1996 and the June 1994 to June 1995 time periods. Due to the existence of a 2 yr life cycle, this required the calculation of individual cohort production during these 2 time periods. At each of the stations sampled during January 1996, the production of the 1994 cohort during the June 1995 to June 1996 time period $\left(P^{\mathrm{cs}}{ }_{1994}\right)$ was computed by using the following equation:

$$
P^{\mathrm{cs}}{ }_{1994}=P^{1}{ }_{1994} \times D^{\mathrm{cs}}{ }_{1994} / D^{1}{ }_{1994}
$$

where $P^{1}{ }_{1994}$ is the production of the 1994 cohort at Stn 1 during the June 1995 to June 1996 time period, $D_{1994}$ is the density of the 1994 cohort at the considered site during January 1996, and $D^{1}{ }_{1994}$ is the density of the 1994 cohort at Stn 1 during January 1996.

We used a similar approach for the calculation of the production of the 1995 cohort during the June 1995 to June 1996 time period $\left(P^{c s}{ }_{1995}\right)$. However, in this case, the production of reference at Stn 1 corresponded to the production of the 1994 cohort at Stn 1 during the June 1994 to June 1995 time period $\left(P^{\prime 1}{ }_{1994}\right)$, leading to the following equation:

$$
P^{\mathrm{cs}}{ }_{1995}=P^{\prime 1}{ }_{1994} \times D^{\mathrm{cs}}{ }_{1995} / D^{\prime 1}{ }_{1994}
$$




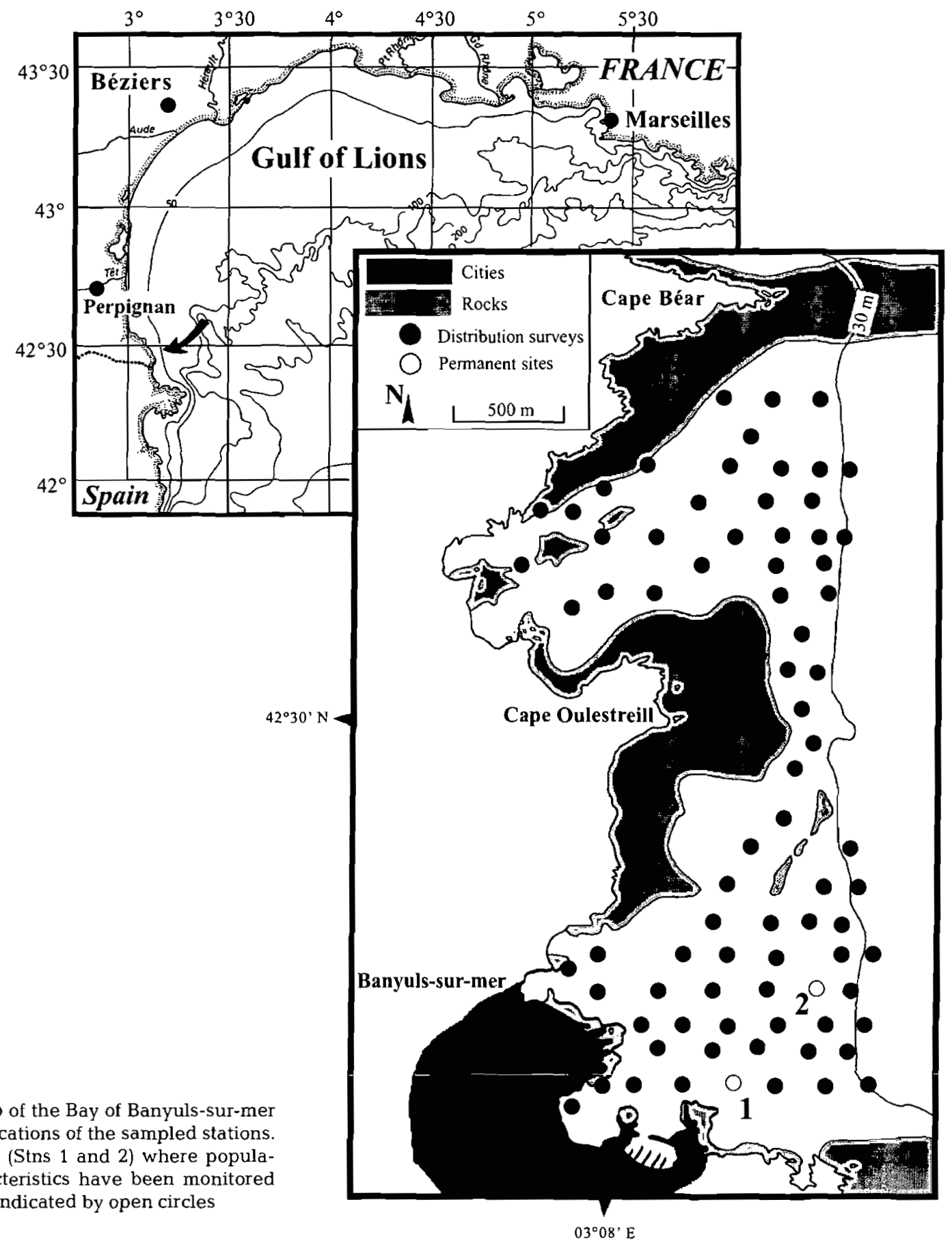

Fig. 1. Map of the Bay of Banyuls-sur-mer showing locations of the sampled stations. The 2 sites (Stns 1 and 2) where population characteristics have been monitored are indicated by open circles

Due to low production during the second year of the where $D^{\text {cs }}{ }_{1995}$ is the density of the 1995 cohort at the considered site during January 1996, and D' ${ }_{1994}$ is the density of the 1994 cohort at Stn 1 during January 1995.

Total production estimates during the June 1995 to

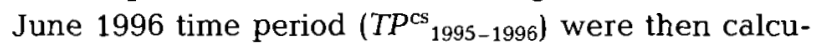
lated by summing the production of the 1994 and 1995 cohorts during this time period:

$$
T P^{\mathrm{cs}}{ }_{1995-1996}=P^{\mathrm{cs}}{ }_{1994}+P^{\mathrm{cs}}{ }_{1995}
$$
life cycle (see 'Results'), the contributions of the 1993 cohort to total productions during the June 1994 to June 1995 time period ( $T P^{\mathrm{cs}}{ }_{1994-1995)}$ ) were neglected. The production of the 1994 cohort during the June 1994 to June 1995 time period ( $\left.P^{\prime c s}{ }_{1994}\right)$ was calculated using the following equation:

$$
P^{\prime c s}{ }_{1994}=P^{\prime 1}{ }_{1994} \times D^{\mathrm{cs}}{ }_{1994} / D^{1}{ }_{1994}=T P^{\mathrm{cs}}{ }_{1994-1995}
$$




\section{RESULTS}

\section{Life history, population structure and population dynamics}

During late oogenesis, the diameters of coelomic oocytes showed a typical bimodal distribution (Fig. 2A). This pattern did not result from heterogeneity among worms since the 2 classes of oocytes were present in most analyzed females. Temporal changes in average oocyte diameters recorded during spring 1996 are presented in Fig. 2B together with those of the proportion of small oocytes (i.e., less than $50 \mu \mathrm{m}$ in diameter). Average oocyte diameters ranged between 48.1 (May 14) and $75.4 \mu \mathrm{m}$ (June 18). They showed 2 relative minima on April 9 and May 14. These minima corresponded to the maximal contributions of small oocytes, which ranged from 1.0 (June 18) to $47.5 \%$ (May 14). This pattern is consistent with what would be obtained by preferentially spawning large oocytes during 2 consecutive spawnings (Bhaud \& Grémare 1991), taking place between March 19 and April 9, and between May 7 and May 14, respectively.

Temporal changes in the number of new recruits found in the sediment traps between 1993 and 1996 are presented in Fig. 3. New recruits were found each year during late spring and early summer, indicating the presence of competent larvae in the water column. Two recruitment peaks occurred during each of these periods. Both the number of recruits and their timing of appearance showed marked differences among years. The highest numbers were observed during 1995, with maximal values of up to 1000 new recruits $\mathrm{m}^{-2}$ wk $^{-1}$ against 150 during 1993 and 1994 or even only 50 during 1996. The first recruits were generally collected during April and their presence in the sediment traps was recorded until the end of June (1993) or even the beginning of July (1994, 1995 and 1996). During 1996, the 2 peaks of abundance of new recruits within the sediment traps occurred on April 23 and June 25, respectively 40 and $52 \mathrm{~d}$ after the 2 spawnings hypothesized from the analysis of temporal changes in average oocyte diameters and contributions of small oocytes (see above).

Temporal changes in the density of post-metamorphic juveniles recorded at station 2 between May 14 and August 26, 1997, are presented in Fig. 4 together with a photograph showing the morphology of the first benthic stage. On May 14, the density of post-metamorphic juveniles was $708 \times 10^{3}$ ind $\mathrm{m}^{-2}$. It then rapidly declined to 0 by August 5 . At this stage, the tube is about $2 \mathrm{~mm}$ long. It is still exclusively made of mucus and is always anchored on sediment grains by a mucous thread.

During January 1996, Ditrupa arietina was present at 47 of the sampled stations (Fig. 5). Densities ranged from 0 to 3550 ind. $\mathrm{m}^{-2}$. They were maximal between 20 and $25 \mathrm{~m}$ depth along the axes of the 2 coves forming the Bay of Banyuls-sur-mer. The population was tightly limited by the $30 \mathrm{~m}$ isobath. Flesh biomass and calcimass per unit of surface area correlated positively with density $\left(\mathrm{N}=46, \mathrm{r}^{2}=0.689\right.$ and 0.676 , respectively, $p<0.001$ in both cases). Size-frequency histograms were either unimodal and composed of large individuals or bimódäl" (22 "stätions) (data not shown). During October 1996, D. arietina was present at 55 of the sampled stations. Densities ranged from 0 to 3000 ind. $\mathrm{m}^{-2}$. They correlated positively with biomass and calcimass $\left(\mathrm{N}=51, \mathrm{r}^{2}=0.840\right.$ and 0.842 , respectively, $p<0.001$ in both cases). Sizefrequency histograms were mostly unimodal and
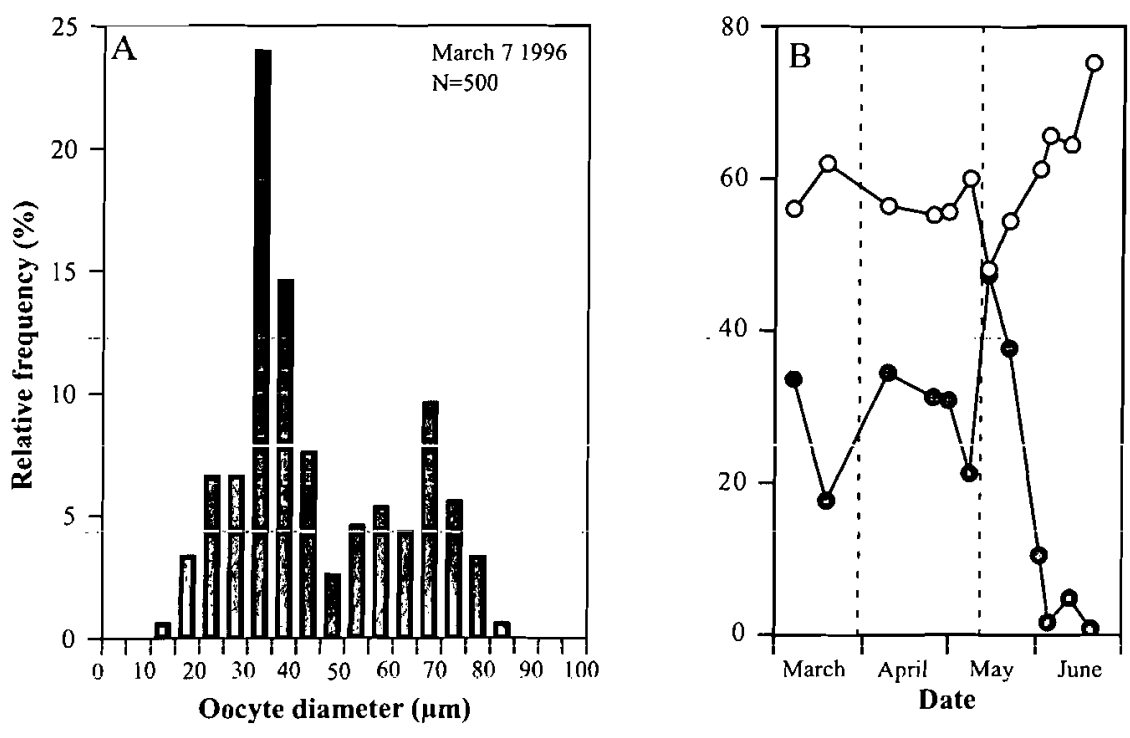

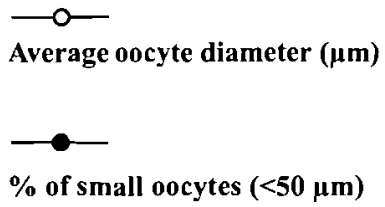

Fig. 2. Ditruna arietina (A) Example of size-frequency histogram of oocyte diameter during late oogenesis. (B) Temporai changes in the average oocyte diameter and in the proportion of small oocytes. Dashed lines indicate the positions of the 2 postulated spawnings (see text for details) 
Fig. 3. Ditrupa arietina. Number of new recruits collected within the sediment traps moored at Stn 1
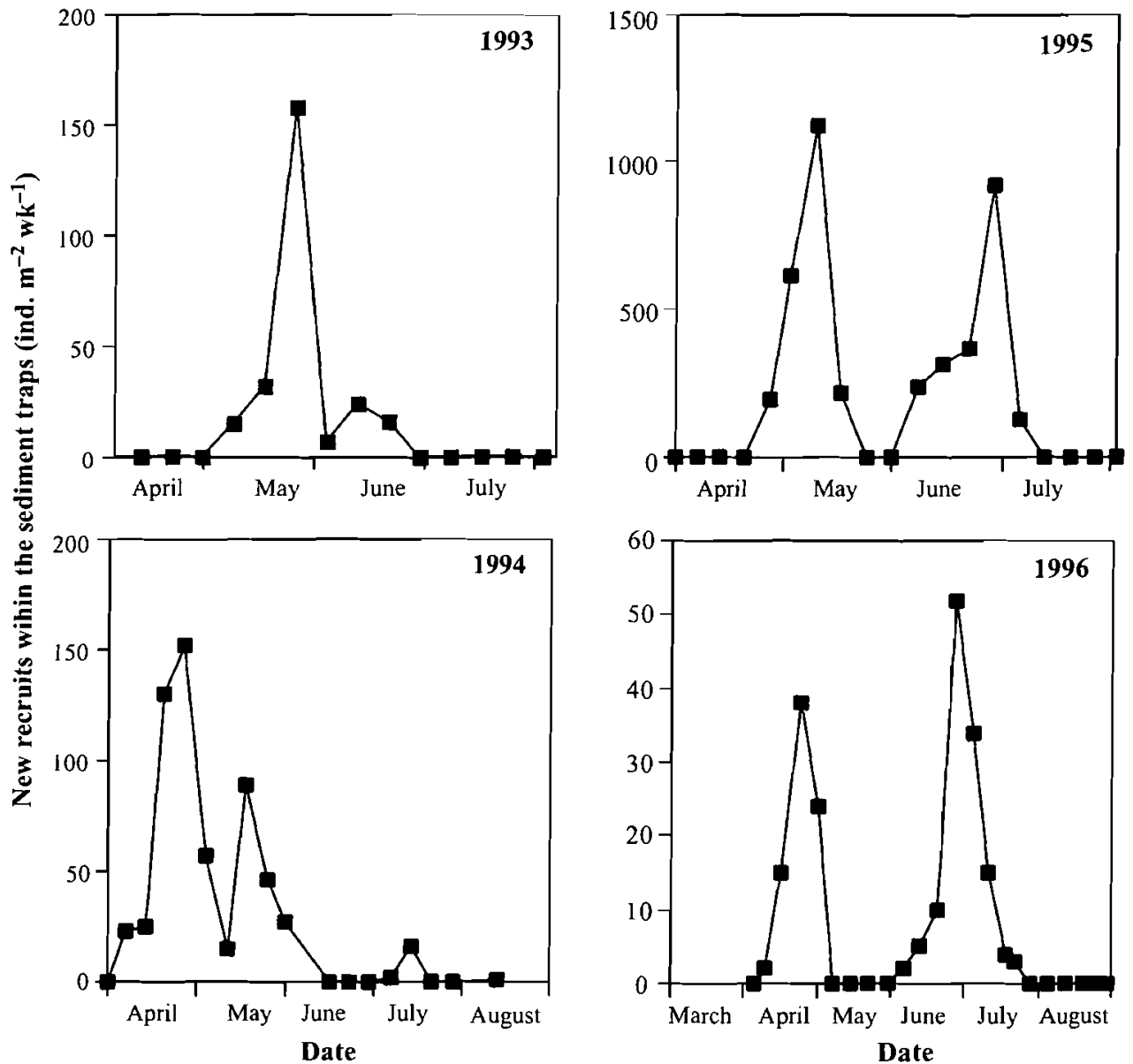

composed of large individuals and only occasionally bimodal (5 stations) (data not shown). When averaged on the whole bay, densities significantly decreased between January and October 1996 (Table 1). This

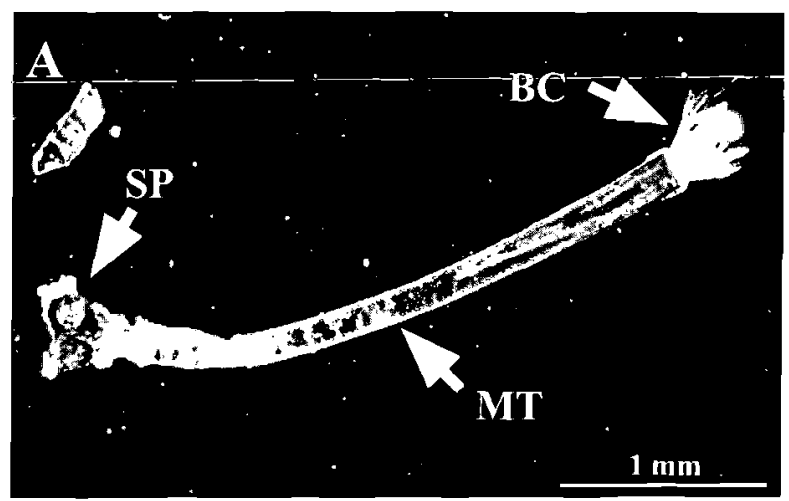

Fig. 4. Ditrupa arietina. (A) Morphology and (B) temporal changes in the density of post-metamorphic juveniles at $\mathrm{Stn} 2$ between May 14 and August 26, 1997. Vertical bars are standard deviations. BC: branchial crown, MT: mucous tube, SP: sediment particles overall decrease was close to $32 \%$. The drop in density was significant in the south cove but not in the north cove (Table 1). In the south cove, this decrease was significant within the 0 to $20 \mathrm{~m}$ depth range but

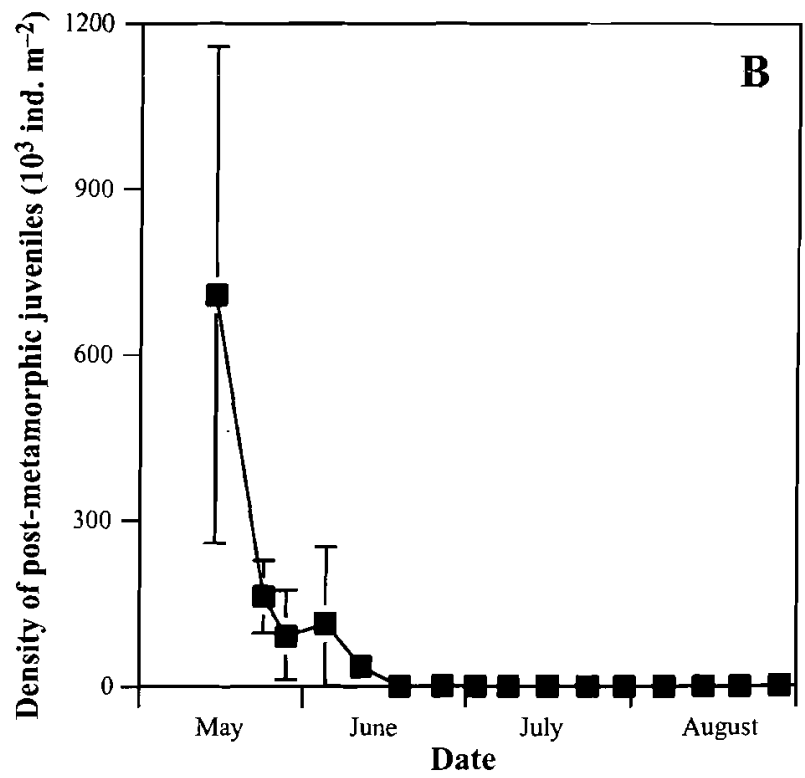




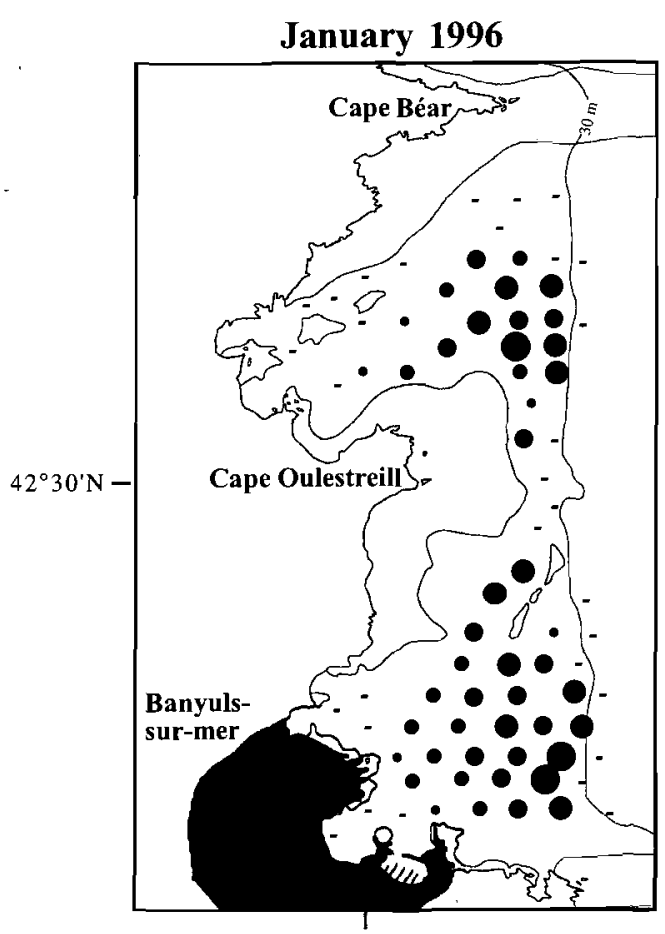

$03^{\circ} 08^{\prime} \mathrm{E}$

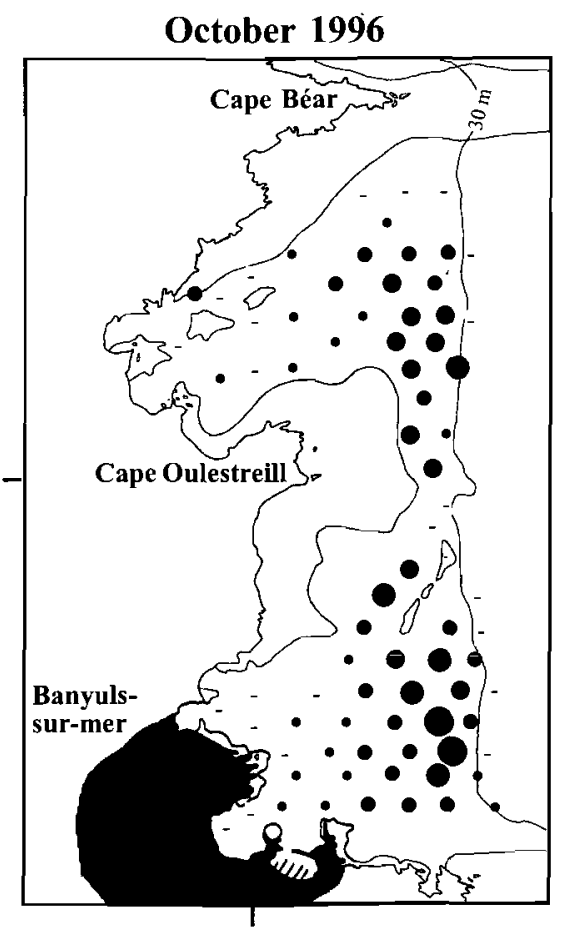

$03^{\circ} 08^{\prime} \mathrm{E}$

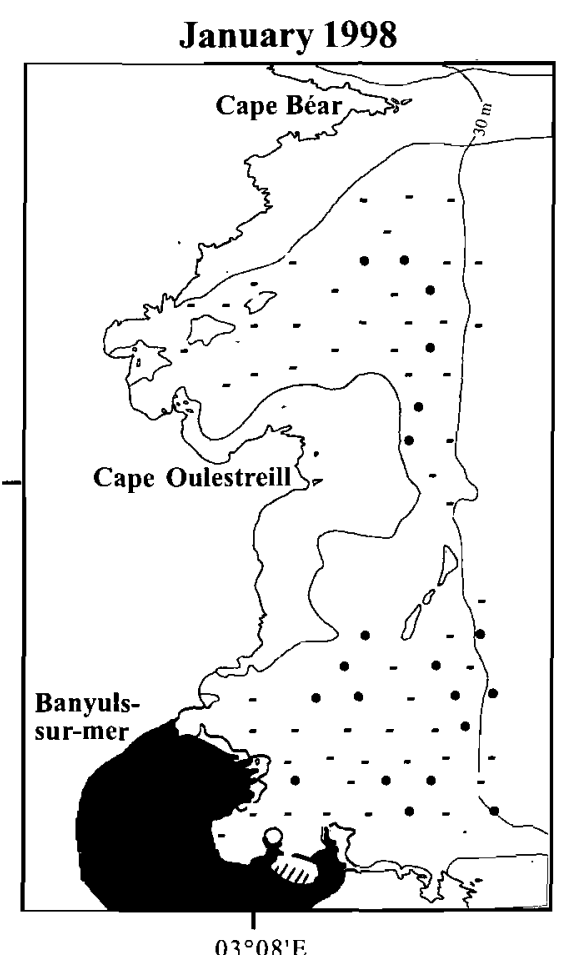

$03^{\circ} 08^{\prime} \mathrm{E}$

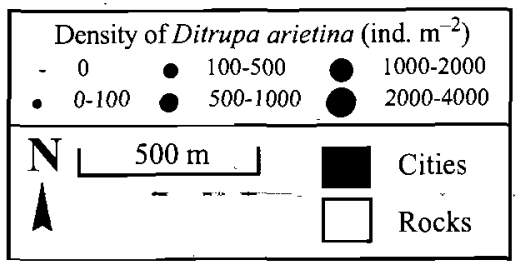

"Fig. 5. Ditrupa arietina. Distribution and densities in January 1996,"October 1996 and January 1998 not within the 20 to $30 \mathrm{~m}$ depth range (Table 1 ). The same trends were found for both flesh biomass and calcimass per unit of surface area (Table 1). During January $1998, D$. arietina was only present at 20 of the sampled stations, with densities ranging from 0 to 25 ind. $\mathrm{m}^{-2}$. The analysis of changes in density with time showed a decline of about $100 \%$ between October 1996 and January 1998.

Temporal changes in adult densities at Stns 1 and 2 are presented in Fig. 6. On June 6, 1994, the density at Stn 1 was close to $20 \times 10^{3}$ ind. $\mathrm{m}^{-2}$. It then steadily declined during the period under study. There were only a few hundred worms per $\mathrm{m}^{2}$ remaining at Stn 1 by late May and early June 1996. Densities at Stn 2 were low. They also tended to decrease during the period under study with less than 100 ind. $\mathrm{m}^{-2}$ remaining by January 1998. Temporal changes in biomass at Stns 1 and 2 are also presented in Fig. 6. At Stn 1, biomass increased from 4 to $12 \mathrm{~g} \mathrm{DW} \mathrm{m}^{-2}$ between June 1994 and June 1995 and then dropped to almost 0 by the end of the period under study. Biomass was low at Stn 2, where its temporal changes tightly reflected changes in densities, indicating an absence of recruitment and subsequent growth during the study period. At both

Table 1. Probabilities associated to the signed rank tests used to compare the density, biomass and calcimass of Ditrupa arietina in various parts of the Bay of Banyuls-sur-mer during both January and October 1996

\begin{tabular}{|c|c|c|c|}
\hline & All $z$ & $-z<20 \mathrm{~m}$ & $z>20 m$ \\
\hline \multicolumn{4}{|l|}{ Density } \\
\hline Whole bay & 0.017 & $<0.001$ & 0.300 \\
\hline North cove & $0.989^{-}$ & $0.672 \cdots$ & -0.827 \\
\hline South cove & 0.006 & 0.001 & 0.163 \\
\hline \multicolumn{4}{|l|}{ Biomass } \\
\hline Whole bay & 0.016 & $<0.001$ & 0.359 \\
\hline North cove & 0.403 & 1.000 & 0.424 \\
\hline South cove & 0.023 & 0.002 & 0.528 \\
\hline \multicolumn{4}{|l|}{ Calcimass } \\
\hline Whole bay & 0.014 & $<0.001$ & 0.291 \\
\hline North cove & 0.438 & 1.000 & 0.569 \\
\hline South cove & 0.019 & 0.003 & 0.433 \\
\hline
\end{tabular}



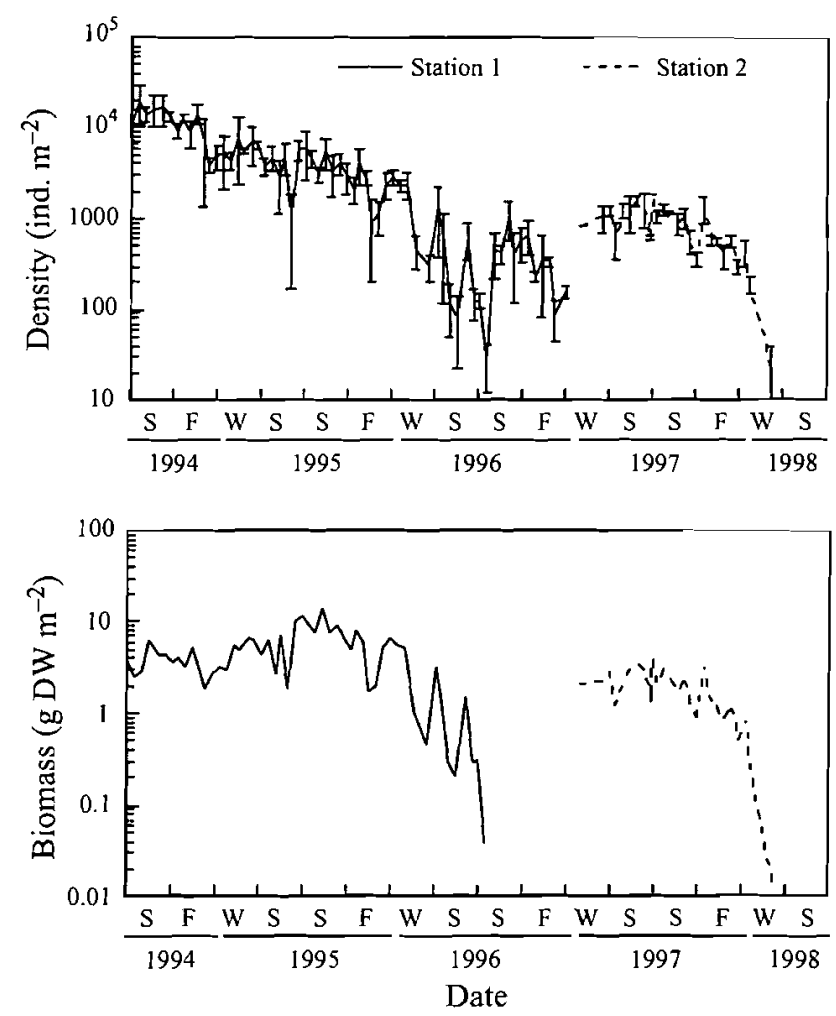

Fig. 6. Ditrupa arietina. Temporal changes in density and biomass at Stns 1 and 2. Vertical bars are standard deviations

stations the ratio between calcimass and biomass always remained close to 40 . Temporal changes in calcimass were thus almost identical to those recorded for biomass.

Temporal changes in size-frequency distributions at Stn 1 are presented in Fig. 7. The June 1, 1994, sizefrequency histogram differed from all the others, since it clearly showed 2 modes in its left tail. However, between June 1994 and March 1995, the frequency histograms were bimodal, which together with the existence of a single period of reproduction per year (see above), suggests that the population comprised 2 cohorts. During this period, the 1994 recruits (i.e., the smallest worms) accounted for more than $95 \%$ of the total population. After March 1995 , almost all frequency histograms were unimodal as the population was nearly exclusively composed of large worms. The 1994 cohort was followed until its total disappearance in June 1996. Mortality was deduced from the density changes of this cohort (Fig. 8). Growth and calcification were assessed from temporal changes of the average dry weights (i.e., flesh and tube) of the worms belonging to the 1994 cohort (Fig. 9). Increases in flesh and tube dry weights were significant during the first year, and almost zero during the second year.

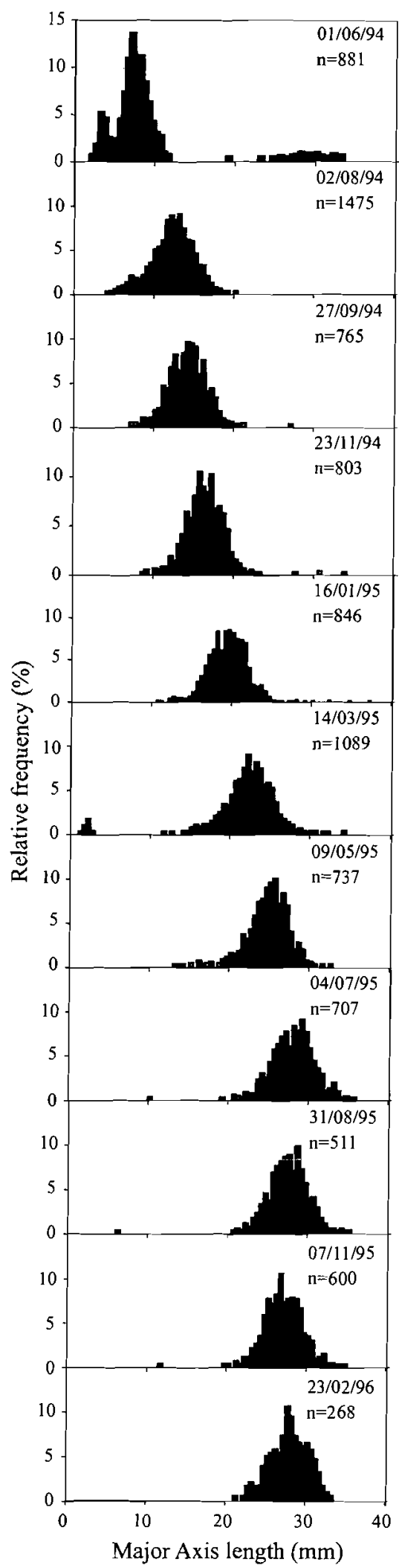

Fig. 7. Ditrupa arietina. Examples of size-frequency histograms recorded at Stn 1 between June 1994 and June 1996. Histograms were selected among the 51 histograms available for this period 


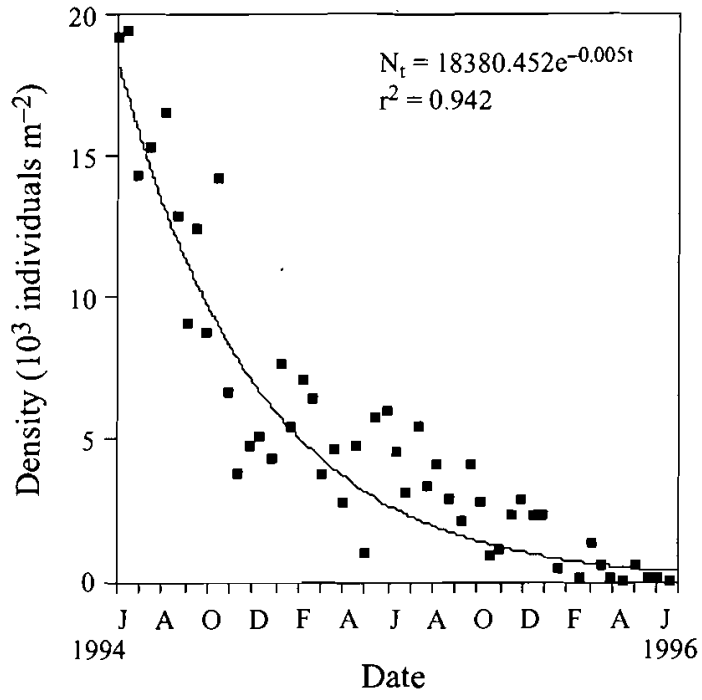

Fig. 8. Ditrupa arietina. Mortality curve recorded at $S \operatorname{tn} 1$ for the 1994 cohort

\section{Production and calcification}

At Stn 1, the production of the 1994 cohort during the June 1994 to June 1996 period was $13.7 \mathrm{~g} \mathrm{DW} \mathrm{m}^{-2}$, with $13.2 \mathrm{~g} \mathrm{DW} \mathrm{m}^{-2}$ produced during the June 1994 to June 1995 time period and $0.5 \mathrm{~g} \mathrm{DW}^{-2}$ produced during the June 1995 to June 1996 time period.. The corresponding $.95 \%$ confidence intervals were $11.6-15.5,11.2-15.2$ and $-0.2-1.1$. The P/B ratio for the June 1994 to June 1995 time period was 2.9 versus only $0.12 \mathrm{yr}^{-1}$ for the June 1995 to June 1996. time period. Calcifications expressed in the same way were respectively $541.8,527.9$ and $13.9 \mathrm{~g} \mathrm{~m}^{-2}$. Their corresponding confidence intervals were 452.3-613.7, 447.7-600.6 and -19.7-40.8.

Because no recruitment occurred at Stn 1 during 1995 (i.e., the whole population was composed of individuals older than $1 \mathrm{yr}$ during the June 1995 to June 1996 time period), the total production at Stn 1 during that year was immediately deduced from the production of the 1994 cohort. The corresponding P/B ratio was $0.12 \mathrm{yr}^{-1}$. During the June 1994 to June 1995 time period, the population at Stn 1 comprised of 2 different cohorts (i.e., 1993 and 1994). Total production could thus be computed as the sum of the productions of these cohorts. The total production during the June 1994 to June 1995 time period at Stn 1 was estimated to he $1.3 .2 \mathrm{~g} \mathrm{DW} \mathrm{m}^{-2}$. The corresponding calcification was $527.9 \mathrm{~g} \mathrm{~m}^{-2}$. The contributions of the 1993 cohort were thus negligible for both secondary production and calcification. The $\mathrm{P} / \mathrm{B}$ ratio for that year was $2.9 \mathrm{yr}^{-1}$.

Secondary production during the June 1995 to June 1996 time period at the stations sampled during January 1996 were between 0.1 and $12.3 \mathrm{~g} \mathrm{DW} \mathrm{m}^{-2} \mathrm{yr}^{-1}$ (Fig. 10). Calcification estimates during the same time
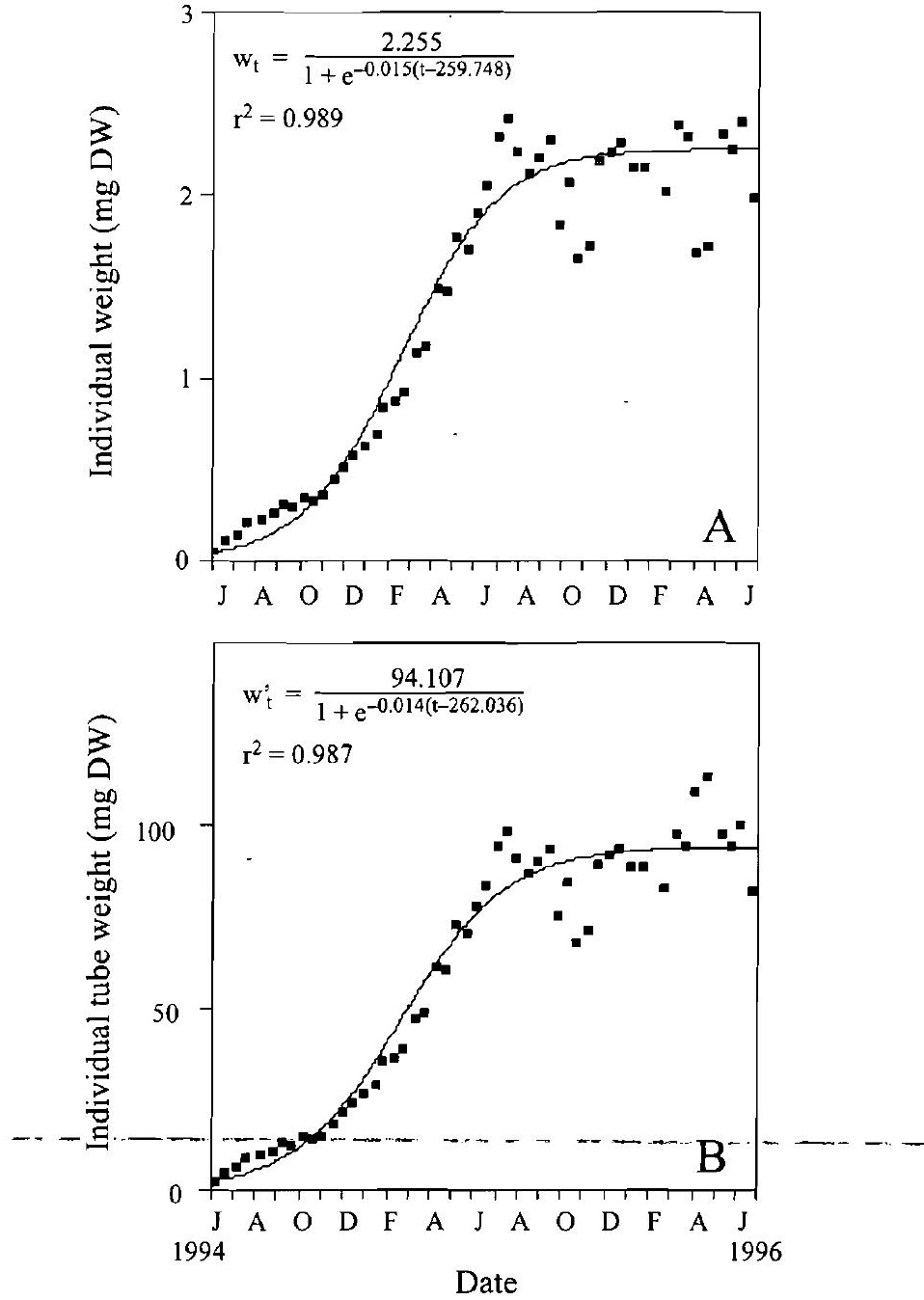

Fig. 9. Ditrupa arietina. Growth curve recorded at Stn 1 for the 1994 cohort. (A) Individual dry weight, (B) tube dry weight

period ranged between 2 and $397 \mathrm{~g} \mathrm{~m}^{-2} \mathrm{yr}^{-1}$ (Fig. 10). Both secondary production and calcification were maximal at the station showing the highest density. Due to the weakness of recruitment during 1995 at most stations, these values were rather low when compared to those obtained during the June 1994 to June 1995 time period (secondary production between 0.4 and $295.6 \mathrm{~g} \mathrm{DW} \mathrm{m}^{-2} \mathrm{yr}^{-1}$ with an average of $54 \mathrm{~g} \mathrm{DW}$ $\mathrm{m}^{-2} \mathrm{yr}^{=1}$, and calcification between 17 and $11836 \mathrm{~g} \mathrm{~m}^{-2}$ $\mathrm{yr}^{-1}$ with an average of $2179 \mathrm{~g} \mathrm{~m}^{-2} \mathrm{yr}^{-1}$, respectively).

\section{DISCUSSION}

\section{Life history}

The monitoring of new recruits within the sediment trap clearly shows that Ditrupa arietina exhibits a non- 

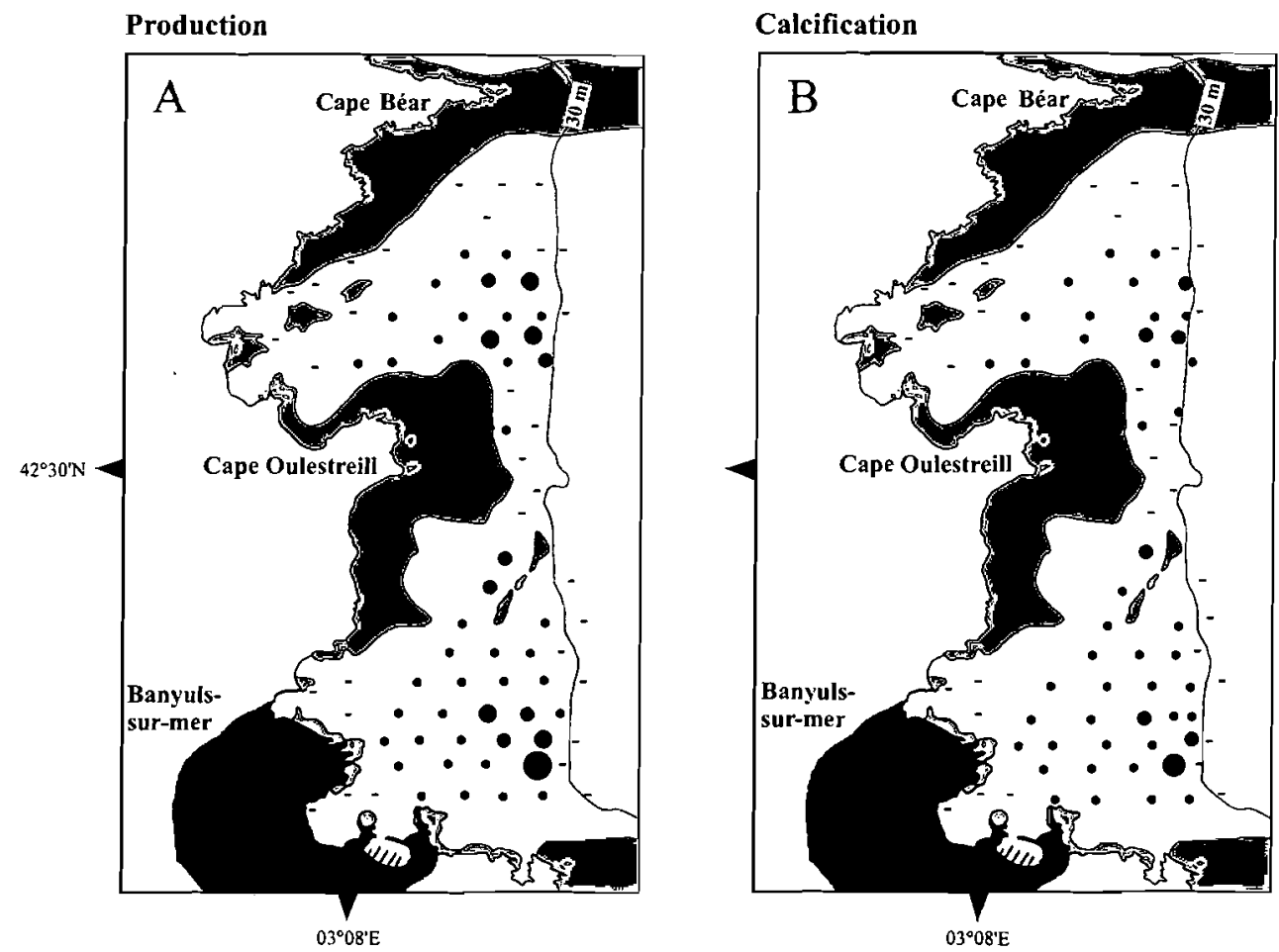

Fig. 10. Ditrupa arietina. Spatial distribution of (A) secondary production ( $\mathrm{g} \mathrm{DW} \mathrm{m} \mathrm{m}^{-2} \mathrm{yr}^{-1}$ ) and (B) calcification $\left(\mathrm{g} \mathrm{m}^{-2} \mathrm{yr}^{-1}\right)$ in the Bay of Banyuls-sur-mer during the June 1995 to June 1996 time period

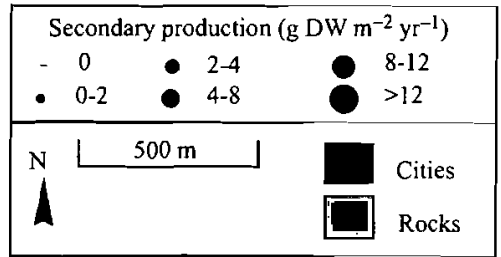

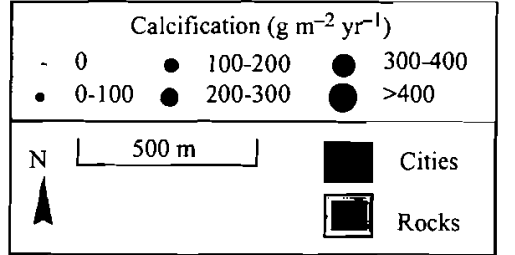

continuous reproduction with 1 extended breeding period per year. In addition, there are several lines of evidence suggesting that individual females spawn several times during that period. First, the size-frequency histograms of oocytes were bimodal just prior the onset of reproduction. Second, temporal changes in average oocyte diameter and in the proportion of small oocytes showed 2 marked changes (probably associated to spawning) during the 1996 breeding season. Third, there were consistently several peaks of recruitment within the sediment traps during the 4 years under study. Fourth, the portion of the size-frequency histograms of benthic populations regarding the new recruits was clearly bimodal just after the end of the 1994 breeding season.

The average oocyte diameter of gravid female was close to $60 \mu \mathrm{m}$. It is in good agreement with those already reported for other serpulids (Wisely 1958, Hill 1967, Crisp 1977). Rullier (1955) reported the presence of oocytes of different sizes in the coelom of $M e r-$ cierella enigmatica gravid females. Hill (1967) and Straughan (1972) reported the occurrence of several spawning and settlement peaks for the same species in both the Lagos Lagoon (Nigeria) and the Brisbane River. Both authors attributed those peaks to a quick reproduction immediately following settlement as indicated by the negative correlation linking the lag between spawning and settlement peaks and water temperature (Straughan 1972). The occurrence of several generations per year in $M$. enigmatica is however largely dependent on high-water temperature according to Dixon (1981), who reported a single generation per year in the Thames estuary. During the present study, we were not able to find any worms reproducing before they were at least 1 yr old.

Daly (1978) reported the existence of an extended spawning period associated with several spawnings per female in a North Sea population of Spirorbis spirorbis. This pattern is thus very close to that observed during the present study. However, in this species, oocytes are large (maximal diameter of $250 \mu \mathrm{m}$ compared to $90 \mu \mathrm{m}$ for Ditrupa arietina) and embryos are incubated in mucous threads, whereas in $D$. arietina, development is planktotrophic (F.C. \& E.J. 
unpubl.) such as is the common rule in serpulids (Rullier 1955, Wisely 1958, Hill 1967, Crisp 1977, Scheltema et al. 1981, Young \& Chia 1982). More generally, extended spawning periods and fractionated spawnings have often been related to incubation via a constraint hypothesis (Grémare 1986). According to this hypothesis, there is a physical (e.g., space) or chemical (gas diffusion) limitation of the number of embryos that can be brooded. Such limitations tend to reduce reproductive output and thus minimize advantages linked to a decrease of larval mortality. This may explain why sophisticated oogenesis mechanisms have evolved in brooding species to allow for the existence of several spawnings during each breeding season. In this sense, it is interesting to point out that extended breeding season including several spawning peaks per individual female can also be found in closely related 'brooders' and 'broadcast breeders' such as Spirorbis spirorbis and Ditrupa arietina.

The analysis of temporal changes in average oocyte diameter and in the contribution of 'small' oocytes suggested the existence of 2 different spawnings during 1996. The comparison of these data with the peaks of recruitment found within the sediment traps shows the existence of a 6 wk time lag. When collected within the traps, the tubes of the newly settled worms were about $5 \mathrm{~mm}$ long. The literature data regarding growth rates of early serpulid juveniles (Qian \& Pechenik 1998), together with the sampling periodicity of the traps, suggest that these worms settled less than $1 \mathrm{wk}$ before collection. The duration of the larval life of Ditrupa arietina is thus probably close to $6 \mathrm{wk}$. Most of the existing data regarding the duration of larval life in other serpulids are based on laboratory rearing experiments. Larval lifespan is negatively affected by temperature (Scheltema et al. 1981). It ranges between a few days for Serpula vermicularis (Young \& Chia 1982) and Hydroides dianthus (Scheltema et al. 1981), and 3 to $6 \mathrm{wk}$ for Mercierella enigmatica (Rullier 1955, Hill 1967. Straughan 1972). Our results are thus in good agreement with those reported for $M$. enigmatica.

During the period under study, population size-frequency histograms were either bimodal or unimodal and always largely dominated by the 1994 recruits. Mortality followed an exponential" model whereas growth was best described by.using a logistic model and became almost zero after the first year. This last pattern complicates the determination of the lifespan, since the occurrence of bimodal size-frequency histograms did not necessarily imply the existence of only 2 year classes. The analysis of temporal changes in density at Stn 1 allows this difficulty to be overcome. During the period under study, this station was largely dominated by the 1994 recruits, which were almost all dead 2 yr after their settlement, thereby suggesting the existence of a 2 yr lifespan. Most of the studies regarding serpulid life history have focussed on development. To our knowledge, there is thus no available data on the lifespan of serpulinae. Nevertheless, the value found during the present study is close to the 16 mo already reported for the spirorbid Spirorbis spirorbis by Daly (1978).

Recruitment did not correlate with the abundance of larvae in the water column as crudely assessed by the number of new recruits collected in the sediment traps moored at Stn 1. During 1994, larval supply was low (less than 150 recruits $\mathrm{m}^{-2} \mathrm{wk}^{-1}$ within the sediment traps) but recruitment was strong. By contrast, during 1995, 'larval supply' was high (occasionally more than 1000 recruits $\mathrm{m}^{-2} \mathrm{wk}^{-1}$ within the sediment traps) whereas, recruitment was much weaker and restricted to the deeper part of the bay. In spite of the presence of competent larvae within the water column during 1996, efficient recruitment within the bay was restricted to only 5 out of the 78 sampled stations with no new recruits at both Stn 1 (no change in density) and 2 (constancy of individual dry weight). In addition, temporal changes of post-metamorphic juvenile density recorded at Stn 2 during the spring of 1997 showed that, in spite of the absence of effective recruitment, high settlement rates immediately followed by drastic mortality rates took place at this station. In this sense, and as in many other benthic invertebrates (see Gosselin \& Qian 1997 for review), the first benthic stages of Ditrupa arietina appear critical in controlling changes in adult density.

\section{Secondary production}

To our knowledge, this is the first quantitative study on secondary production and calcification in a serpulid polychaete. Due to the instability in population structure and the limitation of growth to the first year of the lifespan, secondary production was highly variable from year to year. The differences in productivity of Ditrupa arietina between the 2 years of our study were mainly due to differences in recruitment as already observed by Sarda et al. (1995) for Marenzelleria viridis. At Stn 1, recruitment was strong in 1994 and almost zero in 1995. Consequently, the annual secondary production of Ditrupa arietina was of $13.2 \mathrm{~g}$ DW m ${ }^{-2} \mathrm{yr}^{-1}$ during the June 1994 to June 1995 time period versus only $0.5 \mathrm{~g} \mathrm{DW} \mathrm{m}^{-2} \mathrm{yr}^{-1}$ during the June 1995 to June 1996 time period.

During a previous study, we reported on the heterogeneity of Ditrupa arietina population structure at a small spatial scale (Grémare et al. 1998a). This heterogeneity was confirmed by the results of the pre- 
sent study. Density at Stn 1 during January 1996 was low. Secondary production during the June 1994 to June 1995 time period was thus much higher at other stations. Our estimates of secondary production during this period were between 0.4 and $295.6 \mathrm{~g} \mathrm{DW}$ $\mathrm{m}^{-2} \mathrm{yr}^{-1}$ depending on stations (with an average of $54.5 \mathrm{~g} \mathrm{DW} \mathrm{m}^{-2} \mathrm{yr}^{-1}$ ). We are well aware that these estimates are only crude because: (1) they are partly deduced from differences in densities recorded at the end of the lifespan, and (2) they assume that mortality and growth rates were constant all over the bay. We nevertheless believe that they provide a reasonable idea of the level of secondary production in the whole bay.

These values can be compared with those already available for other polychaetes. A major difficulty in doing so is the heterogeneity in the methods used to assess secondary production (Medernach \& Grémare 1999). When considering only direct methods (Table 2), our June 1994 to June 1995 production estimate at Stn 1 clearly falls in the upper range of literature values. Ditrupa arietina ranks 6 th out of 22 species when production is based on dry weight (maximum of $66.1 \mathrm{~g} \mathrm{DW} \mathrm{m}^{-2} \mathrm{yr}^{-1}$ for Nereis diversicolor, Gillet 1986), and 4th out of 35 species when production is based on ash-free dry weight (maximum of $113 \mathrm{~g} \mathrm{AFDW} \mathrm{m}{ }^{-2} \mathrm{yr}^{-1}$ for Scolelepis gaucha, Santos 1994). Although not obtained by direct methods (see above), our estimations of secondary production within the whole bay during the June 1994 to June 1995 time period would be by far the highest available regarding polychaetes.

Such a high level of production seems primarily related to high biomass per unit of surface area. Indeed, Ditrupa arietina P/B ratio $\left(2.9 \mathrm{yr}^{-1}\right)$ is close to the values given by Sanders (1956) for long lived benthic species and is not in the upper range of literature data. Ditrupa arietina ranks 22 nd out of 51 species for $\mathrm{P} / \mathrm{B}$ ratios (maximum of $12.92 \mathrm{yr}^{-1}$ for Scolelepis gaucha, Santos 1994).

\section{Calcification}

Calcification results both in the sequestration of carbon as calcium carbonate and in the transformation of dissolved bicarbonates into dissolved $\mathrm{CO}_{2}$ (Frankignoulle et al. 1994). Its contribution to the functioning of tropical marine ecosystems has been extensively studied, due to the importance of coral reefs at these latitudes (Buddemeier 1996, Boucher et al. 1998, Gattuso et al. 1998). On the other hand, this process has been largely overlooked in temperate waters (Migné et al. 1998). During the present study, calcification ranged from 1 to $397 \mathrm{~g} \mathrm{~m}^{-2} \mathrm{yr}^{-1}$ for the June 1995 to June 1996 time period. Because recruitment was exceptionally high in 1994, and due to the limitation of calcification to the first year of the lifespan, calcification was much higher during 1994 to 1995 (i.e., between 17 and $11836 \mathrm{~g} \mathrm{~m}^{-2} \mathrm{yr}^{-1}$ ).

In spite of differences in methodologies, these data can be compared with those of the literature regarding temperate ecosystems (latitude $>20^{\circ}$, Collins 1986) (Table 3). The average calcification recorded during 1995 to $1996\left(48 \mathrm{~g} \mathrm{~m}^{-2} \mathrm{yr}^{-1}\right)$ is of the same order of magnitude as those collected in South Florida by Moore (1972) or in West Ireland by Bosence (1980). It is clearly in the lower range of literature data. On the other hand, the average calcification recorded during 1994-95 is about twice higher than the highest value reported so far ( $1278 \mathrm{~g} \mathrm{~m}^{-2} \mathrm{yr}^{-1}$ for a Californian site by Smith 1972). Such a calcification rate is even non negligible when compared to those of major calcifying systems such as corals. In such systems, calcification can reach as much as $12400 \mathrm{~g} \mathrm{~m}^{-2} \mathrm{yr}^{-1}$. However, the average value when considering the whole reef is probably closer to $1100 \mathrm{~g} \mathrm{~m}^{-2} \mathrm{yr}^{-1}$ (Migné et al. 1998). In this sense, and in spite of the instability of Ditrupa arietina population dynamics, our results suggest that calcification should be included in biogeochemical models describing carbon fluxes in temperate benthic ecosystems more often.

Wilson (1979) suggested that Ditrupa arietina may account for as much as $50 \%$ of shell gravels on the outer Scottish shelf. Another interesting point related to calcification is the fate of the calcimass produced by Ditrupa arietina. The number of empty tubes in the Bay of Banyuls-sur-mer is rather low when compared to that expected by combining the density of living animals and the mortality pattern. Smith (1972) also reported a lack of carbonate accumulation in Californian sediments in spite of high calcification rates. Smith (1972) suggested that ' $\mathrm{CaCO}_{3}$ was mechanically removed from its place of formation to adjacent basins where it partially or completely dissolves'. In support of this, we found high numbers of empty tubes at several stations located along the shelf break of the Gulf of Lions with depths ranging from 500 to $1000 \mathrm{~m}$ (Amouroux \& Grémare pers. obs.), whereas living $D$. arietina are usually restricted to depths less than $30 \mathrm{~m}$ (Grémare et al. 1998b). These tubes are thus indicative of a transfer to the deep sea where their dissolution is enhanced.

Acknowledgements. We thank Cécile Fauvelot, Grégory Beaudouin and Hervé Levano, together with several other students for their help during both field and laboratory work. We also thank Aline Migné and co-authors for kindly giving us access to some of their unpublished data. This research was partly funded by the METROMED EEC project and the 'LEA des Sciences de la Mer'. 
Table 2. Compilation of literature data regarding direct estimations of secondary production in polychaetes

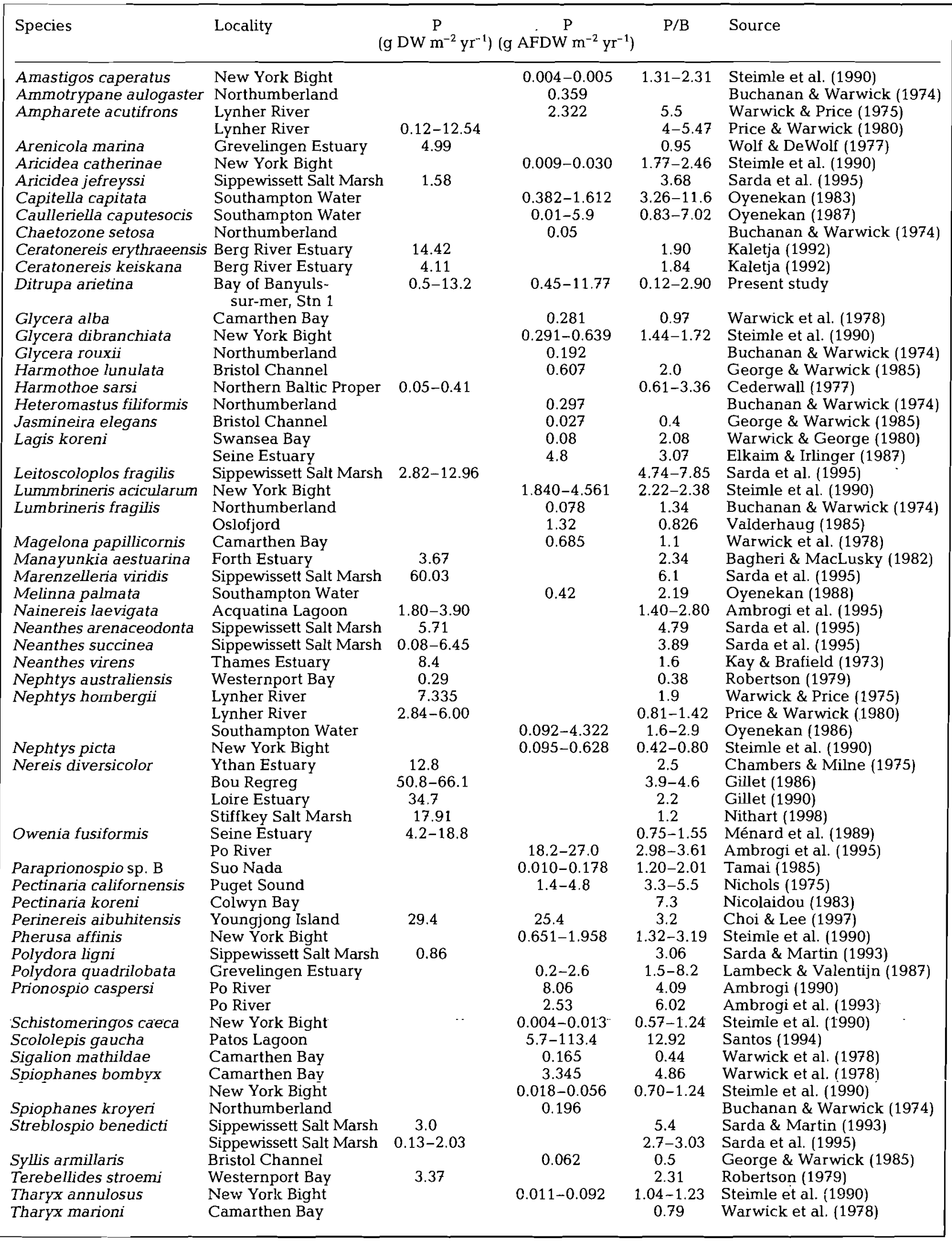


Table 3. Literature data regarding calcification in temperate ecosystems. WC: whole community

\begin{tabular}{|llcrrr|}
\hline Location & Environment or species & \multicolumn{3}{c}{ Calcification $\left(\mathrm{g} \mathrm{m}^{-2} \mathrm{yr}^{-1}\right)$} & \\
& & Min. & Max. & Mean & \\
\hline South Florida & Zone A (WC) & - & - & 38 & Moore (1972) \\
& Zone B (WC) & - & - & 45 & \\
South California & lntertidal mud area (WC) & - & 1000 & 309 & \\
& Bird Rock (WC) & 86 & 915 & 382 & Smith (1972) \\
Pelican Point (WC) & 68 & 4409 & 1278 & \\
Naples Reef (WC) & 927 & 927 & 927 & \\
West Scotland & Bank (WC) & 37 & 462 & 188 & Bosence (1980) \\
English Channel & Muddy algal gravels (WC) & 4 & 144 & 30 & \\
NW Mediterranean & Modiolus-Brachiopod (WC) & - & - & 330 & Collins (1986) \\
& Ophiothrix fragilis & - & - & 682 & Migné et al. (1998) \\
& Ditrupa arietina 1994-95 & 17 & 11836 & 2180 & Present study \\
\hline
\end{tabular}

\section{LITERATURE CITED}

Ambrogi R (1990) Secondary production of Prionospio caspersi (Annelida: polychaeta: Spionidae). Mar Biol 104:407-432

Ambrogi R, Fontana P, Riccobene P (1993) Population dynamics and secondary production of the spionid polychaete Prionospio caspersi in front of the Po delta. Vie Milieu 43: 165-172

Ambrogi R, Fontana P, Gambi MC (1995) Population dynamics and estimate of secondary production of Owenia fusiformis Delle Chiaje (polychaeta, Oweniidae) in the coastal area of the Po River Delta (Italy). In: Eleftheriou A, Ansell AD, Smith CJ (eds) Biology and ecology of shallow coastal waters. Olsen \& Olsen, Fredensborg, p 207-214

Bagheri EA, McLusky DS (1982) Population dynamics of oligochaetes and small polychaetes in the polluted Forth estuary ecosystem. Neth J Sea Res 16:55-66

Bhaud M, Grémare A (1991) Reproductive cycle of Eupolymnia nebulosa (Polychaeta: Terebellidae) in the Western Mediterranean Sea. Ophelia (Suppl)5:295-304

Bosence (1980) Sedimentary facies, production rates and facies models for recent coralline algal gravels CO Galway Eire. Geol J 15:91-111

Boucher G, Clavier J, Hily C, Gattuso JP (1998) Contribution of soft-bottoms to the community metabolism (carbon production and calcification) of a barrier reef flat (Moorea Island, French Polynesia). J Exp Mar Biol Ecol 225; 269-283

Buchanan JB, Warwick RM (1974) An estimate of benthic macrofaunal production in the offshore mud of the Northumberland coast. J Mar Biol Assoc UK 54:197-222

Buddemeier RW (1996) Coral reefs and carbon dioxide. Science 271:1298-1299

Cederwall $H$ (1977) Annual macrofauna production of a soft bottom in the Northern Baltic Proper. In: Keegan BF, O'Ceidigh, Boadaen PSJ (eds) Biology of benthic organisms. Pergamon Press, Oxford, p 155-164

Chambers MR, Milne $\mathrm{H}$ (1975) Life cycle and production of Nereis diversicolor O. F. Müller in the Ythan Estuary, Scotland. Estuar Coast Shelf Sci 3:133-144

Choi JW, Lee JH (1997) Secondary production of a nereid species, Perinereis aibuhitensis in the intertidal mudflat of the west coast of Korea. Bull Mar Sci 60:517-528

Collins MJ (1986) Taphonomic processes in a deep water Modiolus-brachiopod assemblage from the west coast of Scotland. PhD dissertation, University of Glasgow
Crisp DJ (1971) Energy flow measurements. In: Holme NA, McIntyre AD (eds) Methods for the study of marine benthos. IBP handbook no, 16. Blackwell, Oxford, p 197-279

Crisp M (1977) The development of the serpulid Pomatoleios kraussi (Annelida: Polychaeta). J Zool Lond 183:147-160

Daly JM (1978) The annual cycle and the short term periodicity of breeding in a Northumberland population of Spirorbis spirorbis (Polychaeta: Serpulidae). J Mar Biol Assoc UK 58:161-176

Dixon DR (1981) Reproductive biology of the serpulid Ficopomatus (Mercierella) enigmaticus in the Thames Estuary, S.E. England. J Mar Biol Assoc UK 61:805-815

Elkaim B, Irlinger JP (1987) Contribution à l'étude de la dynamique des populations de Pectinaria koreni (Polychète) en baie de Seine orientale. J Exp Mar Biol Ecol 142: $13-23$

Frankignoulle M, Canon C, Gattuso JP (1994) Marine calcification as a source of carbon dioxide: positive feedback of increasing atmospheric $\mathrm{CO}_{2}$. Limnol Oceanogr 39:458-462

Gattuso JP, Frankignoulle M, Bourge J, Romaine S, Buddemeier RW (1998) Effect of calcium carbonate saturation of seawater on coral calcification. Global Planet Change 18: $37-46$

George CL, Warwick RM (1985) Annual macrofauna production in a hard bottom reef community. J Mar Biol Assoc UK 65:713-735

Gillet $\mathrm{P}$ (1986) Contribution à l'étude écologique des annélides polychètes de l'estuairedu Bou Regreg (Maroc). Thèse doctorat d'etat, Université d'Aix-Marseille

Gillet P (1990) Biomasse, production et dynamique des populations de Nereis diversicolor (Annélide Polychète) de l'estuaire de la Loire (France). Oceanol Acta 13:361-371

Gosselin LA, Qian PY (1997) Juvenile mortality in benthic invertebrates. Mar Ecol Prog Ser 146:265-282

Grémare A (1986) A comparative study of the reproductive energetics of two populations of the terebellid polychaete Eupolymnia nebulosa (Montagu) with different reproductive modes. J Exp Mar Biol Ecol 96:287-302

Grémare A, Amouroux JM, Charles F, Dinet A, Riaux-Gobin C, Baudart J, Vétion G, Colomines JC (1997) Temporal changes in the biochemical composition and in the nutritional value of the particulate organic matter available to surface deposit-feeders: a two-year study. Mar Ecol Prog Ser 150:195-206

Grémare A, Amouroux JM, Vétion G (1998a) Long-term comparison of macrobenthos within the soft bottoms of the Bay 
of Banyuls-sur-mer (north-western Mediterranean sea). J Sea Res 40:281-302

Grémare A, Sarda R, Medernach L, Jordana E, Pinedo S, Amouroux JM, Martin D, Nozais C, Charles F (1998b) On the dramatic increase of Ditrupa arietina O. F. Müller (Annelida: Polychaeta) along both the French and the Spanish Catalan coasts. Estuar Coast Shelf Sci 47:447-457

Guille A (1970) Bionomie benthique du plateau continental de la côte catalane française. II. Les communautés de la macrofaune. Vie Milieu (1B):149-280

Hill MB (1967) The life cycles and salinity tolerance of the serpulids Mercierella enigmatica Fauvel and Hydroides uncinata (Philippi) at Lagos Nigeria. J Anim Ecol 36:303-329

Kaletja B (1992) Distribution, biomass and production of Ceratonereis erythraeensis (Fauvel) and Ceratonereis keiskana (Day) at the Berg River Estuary, South Africa. S Afr J Zool 27:121-129

Kay DG, Brafield AE (1973) The energy relation of the polychaete Neanthes (= Nereis) virens (Sars). J Anim Ecol 42 : 673-692

Lambeck RHD, Valentijn P (1987) Distribution, dynamics and productivity of a colonizing (Polydora quadrilobata) and an established $(P$. ligni) polydorid polychaete in Lake Grevelingen: an enclosed estuary in SW Netherlands. Neth J Sea Res 21:143-158

Medernach L, Grémare A (1999) Comparaison de méthodes d'évaluation de la production secondaire d'une population de l'annélide polychète Ditrupa arietina (O. F. Muller). Oceanol Acta 22:337-352

Ménard F, Gentil F, Dauvin JC (1989) Population dynamics and secondary production of Owenia fusiformis Delle Chiaje (polychaeta) from the bay of Seine (eastern English Channel). J Exp Mar Biol Ecol 133:151-167

Migné A, Davoult D, Gattuso JP (1998) Calcium carbonate production of a dense population of the ophiuroid Ophiothrix fragilis: role in the carbon cycle of a coastal ecosystem. Mar Ecol Prog Ser 173:305-308

Moore HB (1972) An estimate of carbonate production by macrobenthos in some tropical soft-bottom communities. Mar Biol 17:145-148

Morin A, Mousseau TA, Roff DA (1987) Accuracy and precision of secondary production estimates. Limnol Oceanogr 32:1342-1352

Nichols FH (1975) Dynamics and energetics of three depositfeeding benthic invertebrate populations in Puget Sound Washington. Ecol Monogr 45:57-82

Nicolaidou A (1983) Life history and productivity of Pectinaria koreni Malmgren (polychaeta). Estuar Coast Shelf Sci 17: $31-43$

Nithart M (1998) Population dynamics and secondary production of Nereis diversicolor in a north Norfolk saltmarsh. J Mar Biol Assoc UK 78:131-143

Oyenekan JA (1983) Production and population dynamics of Capitella capitata. Arch Hydrobiol 98:115-126

Oyenekan JA (1986) Population dynamics and secondary production in an estuarine population of Nephtys hombergii (Polychaeta, Nephtyidae). Mar Biol 93:217-223

Oyenekan JA (1987) Population dynamics and secondary production in an estuarine population of Caulleriella capute. socis (Polychaeta, Cirratulidae). Mar Biol 95:267-273

Oyenekan JA (1988) Population dynamics and secondary production in Melinna palmata (Polychaeta: Ampharetidae). Mar Biol 98:247-251

Price R, Warwick RM (1980) Temporal variations in annual production and biomass in estuarine populations of two polychaetes, Nephtys hombergii and Ampharete acutifrons. J Mar Biol Assoc UK 60:481-487

Qian PY, Pechenik JA (1998) Effects of larval starvation and delayed metamorphosis on juvenile survival and growth of the tube-dwelling polychaete Hydroides elegans (Haswell). J Exp Mar Biol Ecol 227:169-185

Robertson AI (1979) The relationship between annual production:biomass ratios and lifespan for marine benthos. Oecologia 38:193-202

Rullier F (1955) Développement du serpulien Mercierella enigmatica Fauvel. Vie Milieu 6:225-240

Sanders HL (1956) The biology of marine bottom communities. Bull Bingham Oceanogr Coll Yale Univ 15:345-414

Santos PJP (1994) Population dynamics and production of Scololepis gaucha (Polychaeta: Spionidae) on the sandy beaches of Southern Brazil. Mar Ecol Prog Ser 119:159-165

Sarda R, Martin D (1993) Populations of Streblospio (Polychaeta: Spionidae) in temperate zones: demography and production. J Mar Biol Assoc UK 73:769-784

Sarda R, Foreman K, Valiela I (1995) Macroinfauna of a Southern New England salt marsh: seasonal dynamics and production. Mar Biol 121:431-445

Scheltema RS, Williams IP, Shaw MA, Loudon C (198i) Gregarious settlement by the larvae of Hydroides dianthus (Polychaeta: Serpulidae). Mar Ecol Prog Ser 5:69-74

Smith SV (1972) Production of calcium carbonate on the mainland shelf of Southern California. Limnol Oceanogr $17: 28-41$

Steimle FW Jr, Kinner P, Howe S, Leathem W (1990) Polychaete population dynamics and production in the New York Bght associated with variable levels of sediment contamination. Ophelia 31:105-123

Straughan D (1972) Ecological studies of Mercierella enigmatica Fauvel (Annelida: Polychaeta) in the Brisbane River. J Anim Ecol 41:93-105

Tamai K (1985) Production estimation of spionid polychaete Paraprionospio sp. (type B) in Suo-nada, Japan. Bull Jpn Soc Sci Fish Tokyo 51:213-218

Valderhaug VA (1985) Population structure and production of Lumbrineris fragilis (Polychaeta: Lumbrineridae) in the Oslofjord (Norway) with a note on metal contents of jaws. Mar Biol 86:203-211

Warwick RM, George CL (1980) Annual macrofauna production in an Abra community. In: Collins MB (ed) Problems of an industrialized embayment. A case study of Swansea Bay. Pergamon Press, Oxford, p 517-538

Warwick RM, Price R (1975) Macrofauna production in an estuarine mud-flat. J Mar Biol Assoc UK 55:1-18

Warwick RM, George CL, Davies JR (1978) Annual macrofauna production in a Venus community. Estuar Coast Shelf Sci 7:215-241

Wilson J (1979) Biogenic carbonate sediments on the Scottish continental shelf and on Rockall bank. Mar Geol 33: M85-M93

Wisely B (1958) The development and settling of a serpulid worm Hydroides norvegica Gunnerus (Polychaeta). Aust J Mar Freshw Sci 9:351-361

Wolf W.I. DeWolf I. (1977) Rinmass and nroduction of zonbenthos in Grevelingen estuary, The Netherlands. Estuar Coast Shelf Sci 5:1-25

Young GM, Chia FS (1982) Ontogeny of phototaxis during larval development of the sedentary polychaete Serpula vermicularis (L). Biol Bull 162:457-468 